〔ウイルス 第 61 巻 第 1 号, pp.91-98, 2011]

特集 HIV 研究の新しい展開〜第 58 回日本ウイルス学会シンポジウムから〜

\title{
5. ポストバディングに何が起こっているか?
}

\author{
櫻 木 淳 一
}

大阪大学微生物病研究所ウイルス感染制御分野

\begin{abstract}
一般的にレトロウイルス粒子は, 宿主細胞から出芽直後に粒子内ウイルスプロテアーゼが活性化し, 構造蛋白 Gag を切断することで初めて感染性を持った粒子となることが知られている。プロテアー ゼ変異体ウイルスは粒子産生能力は正常に保持しているもののドーナツ様粒子と呼ばれる未熟な粒子 を形成し, 内包するゲノム RNA二量体も非常に脆弱な結合に留まっている。このように正常な粒子 成熟はウイルスが感染能を獲得するために必須の過程であると考えられるが，そのメカニズムについ ては未だ不明な点が多く残されている，今回我々は HIV-1 粒子成熟過程とウイルスゲノム成熟の関 係について解析を試みた，粒子形成した Gag 前駆体P P 55 の切断によって起こる HIV-1 の成熟過程は 斉一なものではなく，いくつかの段階が存在している可能性が示唆されている，我々はその情報を元 に粒子成熟過程が中途段階で停止状態になる一連の変異体を作成し, 粒子成熟過程におけるゲノム二 量体化および粒子形態の変化についての観察を行った，その結果これらの多段階のステップは同期し つつ進行するものの, 各々の転換点は完全には一致していないという興味深い知見が得られた.
\end{abstract}

\section{1.レトロウイルス粒子の成熟}

ウイルス粒子はゲノムを運ぶカプセルであり，一般的に ゲノム核酸と核酸結合蛋白との複合体 (Ribo-nucleoprotein Complex: RNP) と，それを包装する外殼から構成されて いる.レトロウイルスの場合, ゲノムは一本鎖 RNAであり, 核酸結合蛋白であるヌクレオカプシド（NC）とゲノムと の RNP をカプシド蛋白 (CA）からなるコアが包装し，さ らにマトリクス蛋白 (MA) によって裏打ちされた細胞由 来の脂質二重膜が最外殼であるエンベロープを構成してい る ${ }^{1)}$. MA, CA, NC はひとつながりの構造蛋白 Gag 前駆体 （Pr55）として発現され，ウイルス粒子産生時には, Pr55 の形のまま粒子を形成する。通常ウイルスは細胞膜から粒 子形成しつつ出芽 (バディング) し, 直後に粒子内ウイル スプロテアーゼ (PR) が活性化してPr55を切断すること

連絡先

于 565-0871

大阪府吹田市山田丘 3-1

大阪大学微生物病研究所ウイルス感染制御分野

TEL: 06-6879-8348

FAX: 06-6879-8347

E-mail: sakuragi@biken.osaka-u.ac.jp
で初めて感染性を持った粒子となると考えられており 2,3), この過程は粒子成熟と呼ばれる。電子顕微鏡による形態観 察により，このときウイルスは未成熟なドーナツ様粒子か らコアを持った成熟粒子にダイナミックに形態変化するこ とが知られている. 粒子内部に存在するウイルスゲノム RNA は非共有的に二量体を形成しているが, 未成熟粒子 内では精製中に大部分が解離して単量体化してしまうほど に不安定である。これに対し成熟粒子内のゲノムは安定な 二量体を形成している ${ }^{4)}$.つまりウイルスの粒子成熟はポ ストバディングに起きる劇的なイベントであり, 粒子内外 の形態を完成させて感染能を獲得するために必須の過程で あると言えるが，始まり（プロテアーゼ不活化ウイルス等 由来の未成熟粒子）と終わり（野生株由来の成熟粒子）に ついての知見があるだけで，ゲノム二量体化はいつ始まり いつ完成するのか，粒子の形態変化はどのように進行する のかといった過程に関する多くのことは未解明であった （図 1). 我々は粒子成熟に伴う，二量体化を含むゲノム RNA 成熟と粒子感染能獲得との関連についていくつかの 実験を行い, 検討・考察を行った，以後「二量体化」とい う用語は主として「レトロウイルスゲノム RNA二量体の 均一／安定化」を意味するものとして使用する。

\section{2. ゲノム成熟に重要な Gag 切断点の解析}

レトロウイルスである HIV-1に注目すると，粒子成熟 


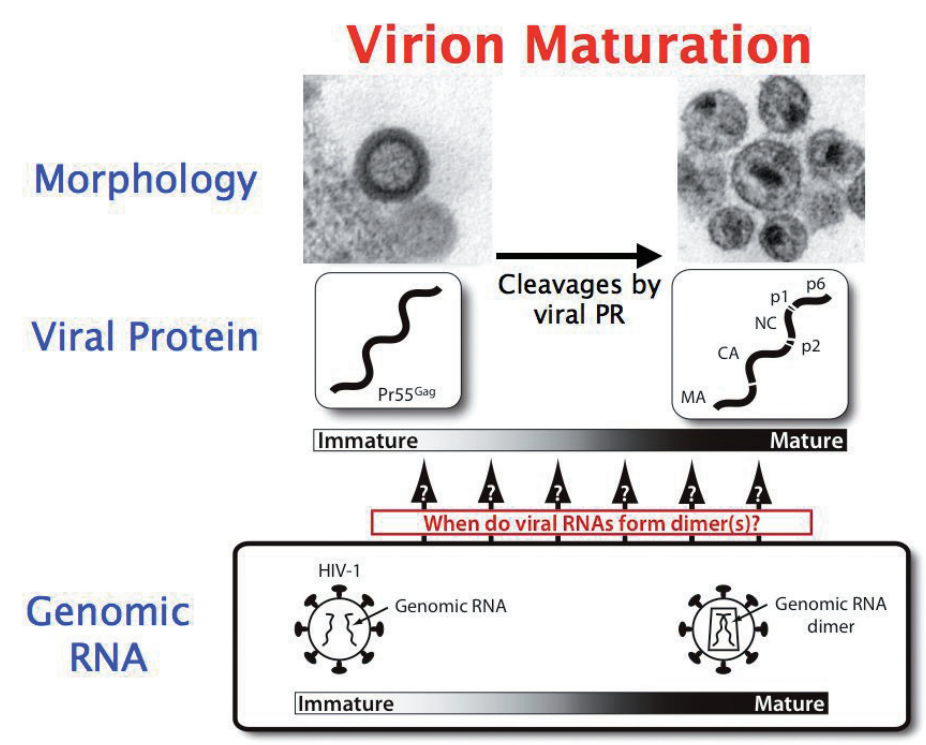

図 1 HIV-1 粒子成熟過程の概念.

A
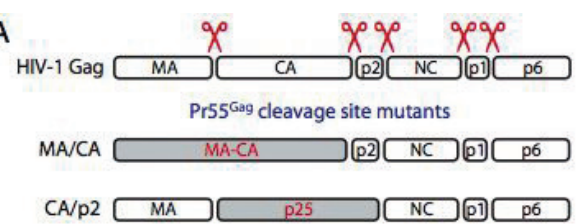

p2/NC MA $C C_{\text {A }}$

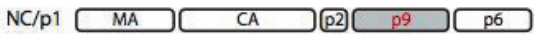

$\mathrm{p} 1 / \mathrm{p} 6 \mathrm{MA} \longrightarrow \mathrm{CA}$

B
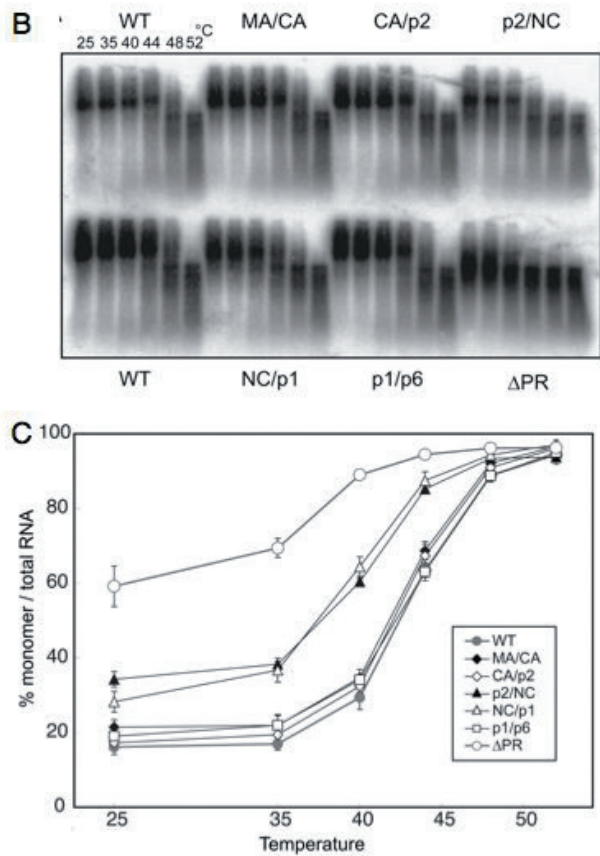

図 2 Pr55 各切断点不活化変異体と，そのゲノム RNA． A) 変異体の模式図． B) ゲノム RNA のネイティブノザンブロット，ウイルスゲノ 厶を非変性状態で粒子から回収・精製して分注し，様々な温度で恒温した後電気泳動した，25-35ㄷの常温条件ではゲノムは二量 体であり，50C を超えると解離して単量体化する，p2-NC および NC-p1のみ常温でも単量体が若干存在する． C) ブロットの定量 化グラフ. 
A

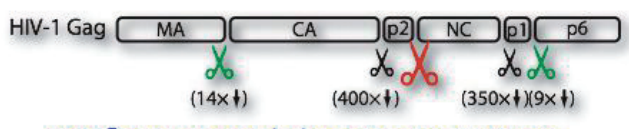

Pr55 $5^{\mathrm{Gag}}$ sequencial cleavage site mutants

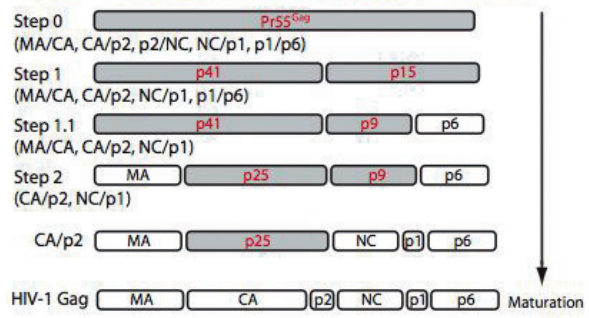

B

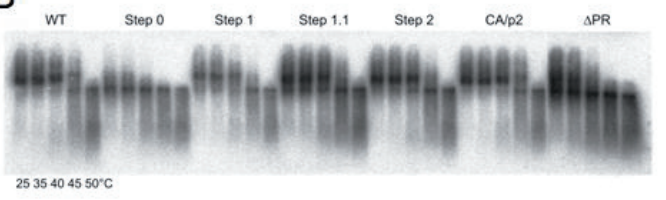

C

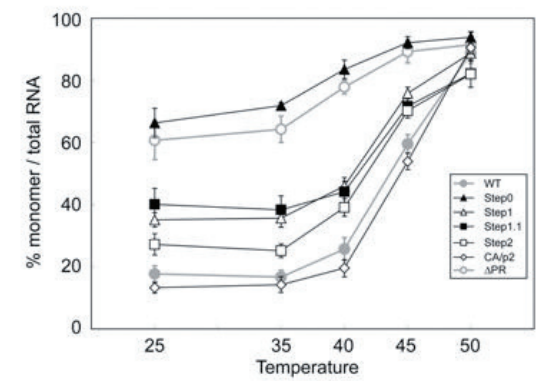

図 3 Pr55 成熟ステップ変異体と，そのゲノム RNA．A) 変異体の模式図． B) ゲノム RNA のネイテイブノザンブロット. 多〈の変異体 で常温時に単量体が存在している．C) ブロットの定量化グラフ.

は Gag 内の 5 箇所の切断点が PR によってプロセシングさ れ，6つの Gag 由来蛋白が作り出されることによって起 こる. Gag 由来蛋白は $\mathrm{N}$ 末から順に MA, CA, p2, NC, p1, p6 であり, p6 は粒子放出に重要な役割を持つことが知ら れるが, 分子量の小さい $\mathrm{p} 2, \mathrm{p} 1$ の果たす役割は明瞭になっ ていない. 我々は研究の端緒として, これらのうちゲノム RNA 成熟に重要な切断点を知る目的で, 各切断点を不活 化した一連の変異体を作成し, ウイルスゲノムの二量体化 を調べた（図 2)。その結果 NCの末端が切断されない二 つの変異体（p2/ NC, NC/p1）のゲノムのみが一部不安定 な二量体化に留まっていることが確認され，NCが完成さ れることがウイルスゲノムの成熟に重要であることが明ら かとなった。この結果は以前の報告を裏付けるものであった 5 , 6)

\section{3. ウイルス粒子成熟過程を再現する一連の変異体の解析}

これまでに生化学的な解析によって Gag の 5 箇所の切 断速度はそれぞれ異なることが報告されている ${ }^{7)}$ 。精製蛋 白を用いたIn vitro 実験結果によると，まず最初に p2-NC が切断を受け，その 10 倍前後の時間をかけて p1-p6が, 次いで MA-CA が切断される。 さらに数百倍の時間をかけ て NC-p1，CA-p2 の順に切断され，プロセスが完了する. つまり切断は順を追って起きるため粒子成熟過程は斉一な ものではなく，いくつかのステップが存在していると考え られる。成熟は粒子放出と同時期に進行すると考えられる 一方で，粒子放出の夕イミングを実験的にコントロールす ることは非常に難しいため，これまでに成熟過程のステッ プを厳密に解析する試みは為されていなかった。我々は各 切断点の不活化変異を組み合わせ, 二重から五重変異を Gag に導入することで粒子成熟過程が中途段階で停止状態 になる一連の変異体を作成した（図 $3 \mathrm{~A}$ )。すべての切断
点が不活化し, PR 不活化変異体と同様に Gag 前駆体 Pr55 のみを発現するStep0, p2-NCのみが切断し, MA/CA/p2 と $\mathrm{NC} / \mathrm{p} 1 / \mathrm{p} 6 （ \mathrm{p} 15 ）$ のつの融合蛋白を持つ Step1, さ らに MA-CA が切断した Step1.1, p1-p6 が切断してCA/ $\mathrm{p} 2$ と $\mathrm{NC} / \mathrm{p} 1$ のみ融合蛋白として残る Step2 に加え, もっ とも切断が遅いと考えられる $\mathrm{CA} / \mathrm{p} 2$ のみを融合蛋白とし て残す CA-p2 変異体も並べて比較検討を行った。 まずこ れらの変異体の持つゲノム RNAの性状を様々な角度から 解析した（図 3，4）。ゲノム二量体化に関しては，Gagの 最初の切断点である $\mathrm{p} 2-\mathrm{NC}$ の切断により二量体の安定化 が一気に起きるがそれは十分ではなく, 引き続いて起こる 蛋白成熟によって二段階の中間体形成を経て CA-p2 変異 体のステップでようやく均一で安定した二量体が完成する ことが示唆された（図3B，C）。ゲノムRNAの見かけの分 子量分布の解析からは, Step1 で出現する二量体は見かけ の分子量が大きく, やはり二段階の中間体形成を経るが二 量体の安定化とは異なるパターンを経ていることが明らか となり（図 4A，B），RNAの泳動プロファイルの複雑な変 遷も併せて観察されたことからも (図 4C), RNA 成熟過 程には多彩な反応が起きていることを伺わせた.

\section{Gag 前駆体切断の量論的解析}

Step0 から Step1への 1 段階でゲノム二量体化が劇的に 進行することが明らかとなったため, これに関して量論的 な解析を試みた。 すなわち, ウイルス粒子内に 3000 分子 程度存在すると考えられる Gag 前駆体のうち, 何\%が切 断を受けると二量体化が始まるのかという命題である。そ こでStep0 とStep1の混合比率を様々に変えて共発現さ せ, 二種の変異 Gag が一定比率で混合しているいわば “半 熟”ウイルス粒子のゲノム RNA二量体化効率を測定した. 単純に考えればプロセシングの程度が同じ粒子は RNAの 

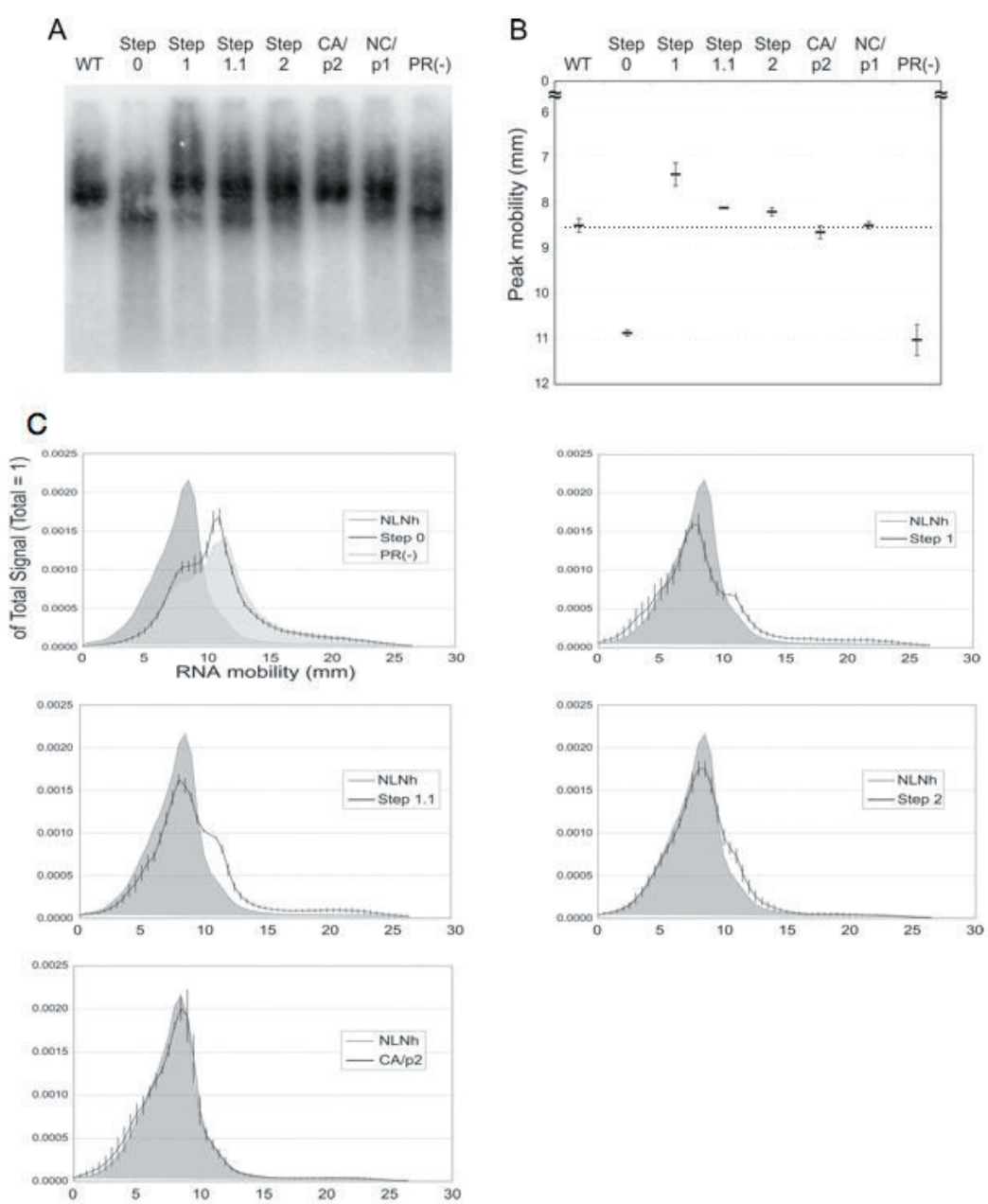

図 4 成熟ステップ变異体の RNA 性状. A) 常温状態のゲノム RNA ブロットの比較. B)二量体の泳動移動度の比較. 点線は野生株 (WT) の移動度を示す. C)RNAの分子量分布. Step0 はプロテアーゼ不活化変異体 (PR(-)) とほぼ同様の分布. 野生株 (NLNh) と比べて, Step1 は高分子側と低分子側にそれぞれ高いシグナルがある. Step1.1と2では高分子側はなくなるが, 依然低分子側のシグナル が残る. CA/p2 に至って野生株とほぼ同様の分布になる.

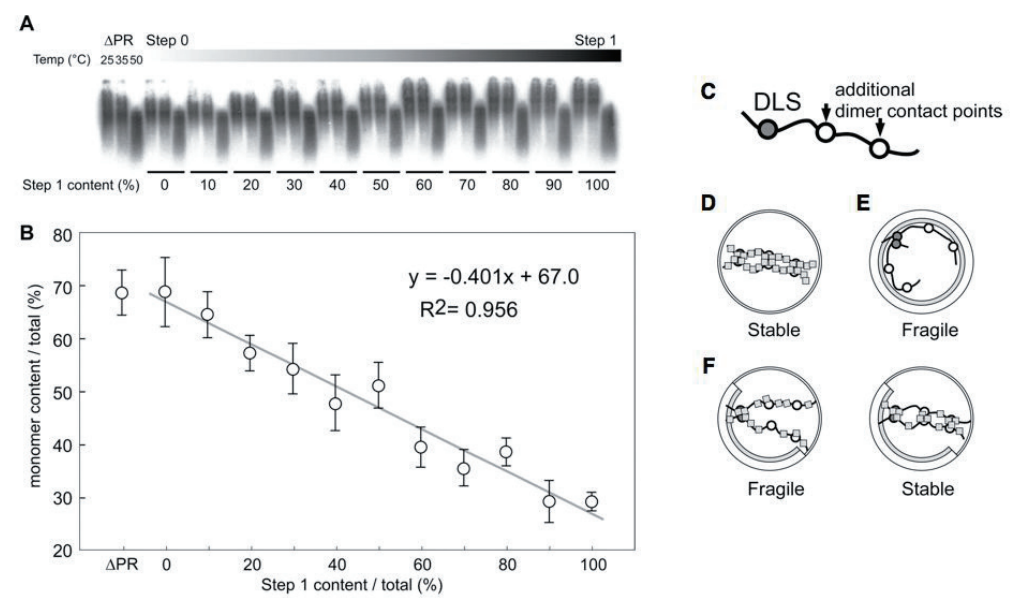

図 5 二量体化の閾值についての量論的解析．A) 変異体混合粒子のゲノム RNA ブロット. B) ブロットの定量化グラフ. 右に行くほど成 熟が進むことになり，二量体化もリニアに進行している，C)-F)二量体化モデル。詳細は本文. 
A

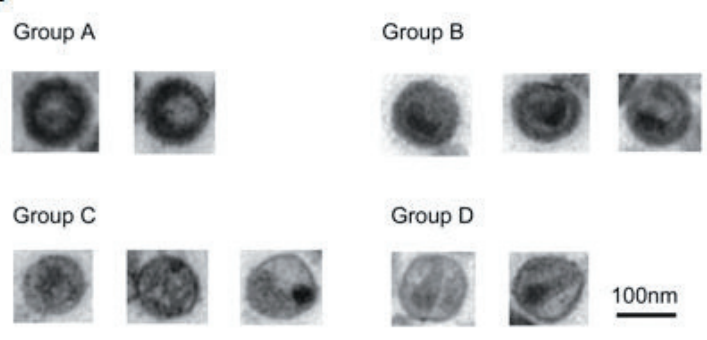

B

\begin{tabular}{ccc}
\hline group & core & envelope \\
\hline A & ring-shaped & thick \\
B & amorphous & thick \\
C & amorphous or non-conical & thin \\
D & conical & thin \\
\hline
\end{tabular}

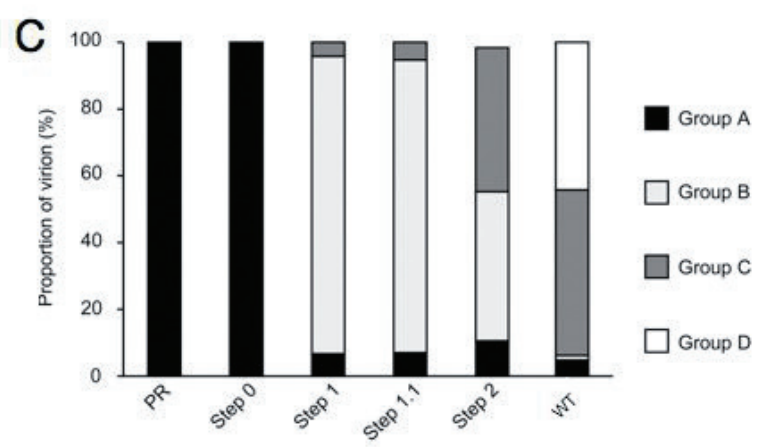

図 6 粒子成熟の形態変化. A) 形態のグループ分け. B) グループ分類の指標. C) それぞれの変異体の形態分布.

二量体化も同程度に揃うはずで, Gag 混合粒子の RNA二 量体化効率は Step0 型（不安定型）になるか Step1 型（安 定型）になるかのどちらかしか無い，つまり二量体化の闇 值の存在が予想された。しかし結果としてはStep0から Step1 まで二量体化はリニアに変化し，閾值は何処にも認 められなかった（図 5A，B）。このことはたとえプロセシ ングの程度が同様であっても，粒子によって RNA が二量 体化していたりいなかったりする，つまり確率的なもので あるということを示しており，興味深いものであった。こ れについての一つのモデルを以下に示す（図 5C-F)。C) ウイルスゲノムは 5 末端近くに位置する二量体化シグナ ル領域（DLS）で物理的に結合している8) が, DLSの他 にも安定な二量体形成に働いている領域として二量体接触 点 (Dimer Contact Point: DCP) がゲノム上に複数存在す ると仮定した，DLS や DCP は NC が介在することで二量 体形成を開始し, 安定化に寄与する。 D) Step1 粒子では $\mathrm{NC}$ を含む蛋白 $\mathrm{p} 15$ が粒子内で自由に動け, ゲノム全体を
覆うのに十分な分子数が供給されるので二量体は安定化す る. E ) 一方, 自由な p15 が存在しない Step0 粒子では DLS や DCP が NCによって相互作用することが出来ず, 二量体は不安定である，F）半熟粒子においては自由な p15の分子数が足りないのでゲノム全体を覆うことが出来 ない. NCとゲノムの結合は確率的なので, すべての DCP が 15 と結合したゲノムは安定した二量体を形成できる (Stable)が,そうでなければ不安定なままになる (Fragile).

\section{5. 各変異体の電顕像による粒子形態変化観察}

電子顕微鏡を用いて精製变異体粒子の形態学的観察を 行った. エンベロープ形状と粒子内部の構造を元に粒子形 態を 4 種類に分類し, それぞれの変異体における形状の分 布を集計した（図 6). 粒子成熟度はAから Dへ向かって 進行するものと考元られる. その結果 Step0 から $1,1.1$ から 2 , および 2 から野生型へのステップでそれぞれ粒子 形状分布の大きな変化が観察され，これらの変化はゲノム 二量体化状態の変遷ともよく一致した。一方で形態変化が 

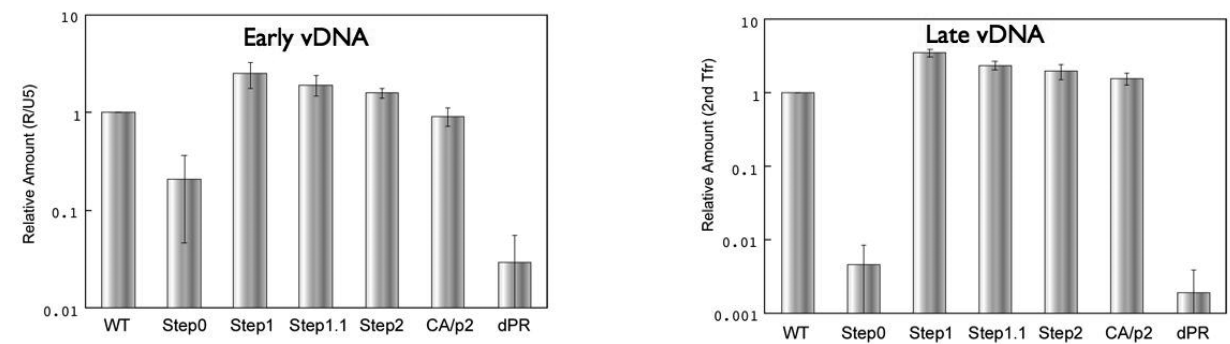

図 7 ウイルス粒子内在性逆転写アッセイの結果. 上は初期産物，下は後期産物を示す．野生株を1とした.

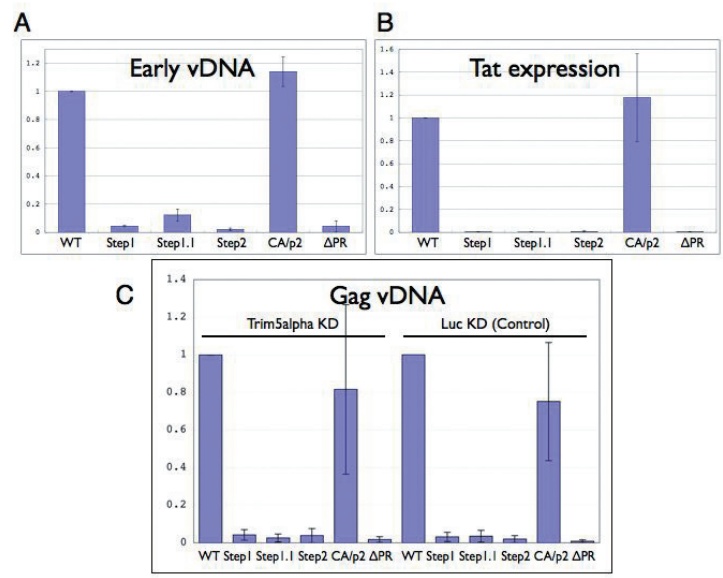

図 8 T 細胞系におけるウイルス感染能の比較. A) 感染 18 時間後の細胞内のウイルス DNA 量 (初期産物). B)レポーター細胞を用い たウイルス感染 48 時間後の細胞内 Tat 発現量. C)Trim5 a ノックダウン細胞とコントロール細胞の感染 18 時間後の細胞内のウイ ルス DNA 量. 野生株を1とした

見られないStep1 から 1.1 のステップでもゲノムは二量体 の見かけの分子量という点で大きく変化しており（図 4), ゲノム二量体化過程のすべてが粒子形態変化に反映されて いるわけではなかった。またゲノム二量体化にはウイルス コアの形成（GroupD）は必要なく，コア形成より遙かに 前に二量体化は進行することも明らかとなった。

\section{6. ウイルス粒子成熟と感染能獲得}

粒子成熟のどの時点でウイルスの感染能が獲得され，ゲ ノム RNA にはどのような状態が必要とされるのかについ て検討を行った。まずゲノム RNA がウイルスの逆転写酵 素（RT）によって逆転写され DNA 化する能力を獲得す る過程を知るためにウイルス粒子の内在性逆転写アッセイ を行った。 ウイルス粒子を精製し界面活性㓮と dNTPs 加えて酵素反応を行わせ, 粒子の逆転写産物生成量をリア ルタイム PCRにより定量した（図 7)。その結果 Step0 か ら Step1の段階でウイルス粒子内の逆転写産物は飛躍的に 増加し野生株産物の 3 倍前後に達し, さらなる成熟過程を 経て産生量は緩やかに減少しつつ野生株のレベルに到達し た.この傾向は逆転写初期産物でも後期産物でも変わらず, ウイルスゲノム RNA は p2-NC 切断の時点で既に十分以上
に逆転写を受ける能力を獲得することが明らかとなった． NCには逆転写促進などにも関わると考えられる RNAシャ ペロン能があることが知られている ${ }^{9)}$. しかしこの能力は $\mathrm{NC}$ が完全に単離されて初めて十分になることが指摘され ており 10)，NCがポリ蛋白 p15のままのStep1 変異体に おいてこのような高効率の逆転写を実現することは意外な 結果であった，そこで逆転写効率向上のトレードオフとし てその精度が低下している可能性を疑い，内在性逆転写産 物のシークエンスを行った。後期産物について調べたが野 生株と Step1 変異体産物のシークエンスエラー率はまった く同等であり, 結果として Step1 変異体 RNAの被逆転写 能は野生株を大きく凌駕するものであった。

最後に変異体の細胞への感染能についても比較を行った (図 8)。T細胞系への一過性感染実験を行い細胞内ウイル 久逆転写初期産物と Tat の発現について定量した結果，粒 子成熟の最終段階である CA-p2 変異体になって初めて野 生型と同等な感染価を示した（図 $8 \mathrm{~A}, \mathrm{~B})$ 。 ウイルス粒子 内在性逆転写能の結果と比べると遙かに遅い夕イミングで あり，ゲノム RNA は成熟の初期から被逆転写能を獲得し ているにもかかわらず，ウイルスの細胞への感染には NC の完全な成熟が必要であるという非常に興味深い結果と 


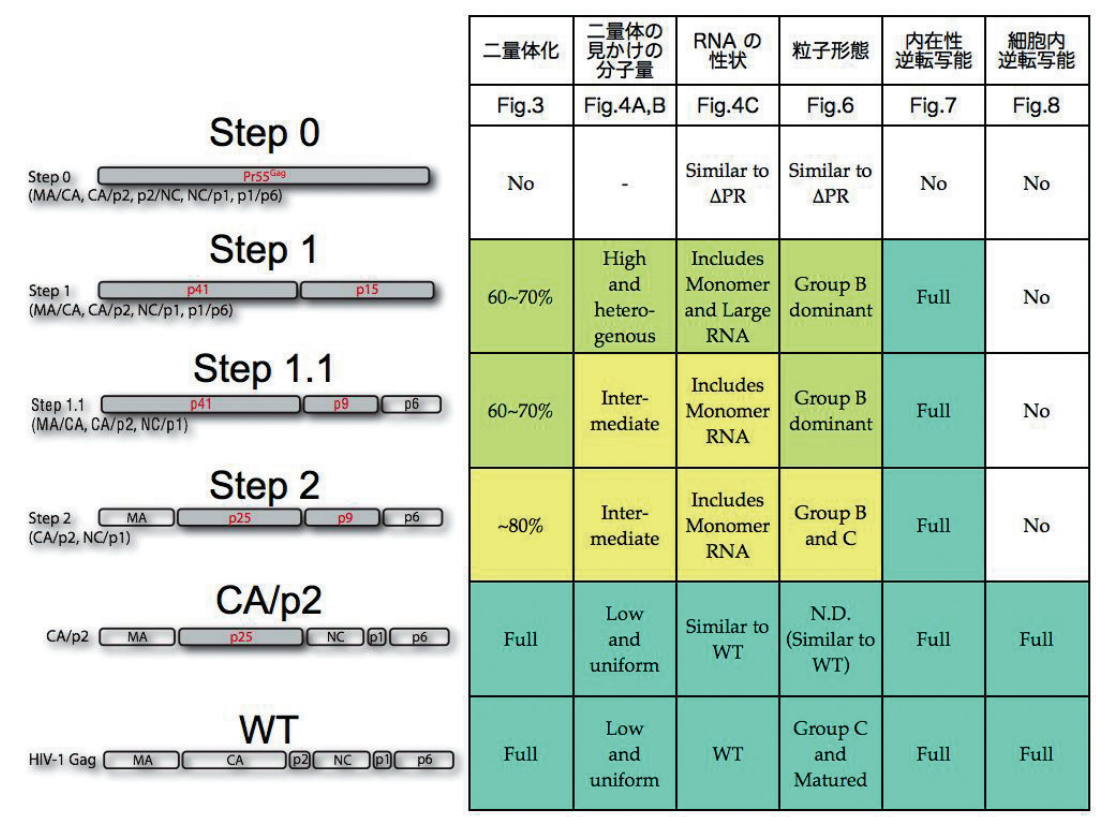

図 9 ウイルス粒子成熟に伴う種々の変化のまとめ.

なった，未熟なウイルス RNAの逆転写以前に細胞性の阻 害が存在する可能性があるという事象は, 抗ウイルス因子 Trim5 a の関与を疑わせた ${ }^{11)}$. ヒト由来 Trim5 a にはほ とんど抗 HIV-1 能が無いことは知られているが, 未熟粒 子に対する効果についての検証は今まで無かった。このた め Trim5 aノックダウン細胞を用いて感染能測定を行っ たが，ノックダウンの有無に結果は影響されず Trim5 a の関与は認められなかった（図 8C).

\section{7. 考察}

これまでの結果を一覧表にして示す（図 9)。活性化し た PRによる Gag の切断により粒子成熟やゲノム二量体化 が起こることは知られていたが，今回の解析によりこの二 つの多段階のステップは同期しつつ進行するものの, 各々 の転換点は完全には一致していないという興味深い知見が 得られた ${ }^{12)}$. 結果から考えられるストーリーは以下のよ うになる。 まず Pr55 が切断されていない段階で粒子形成 が起き，DLSを介して二量体化したウイルスゲノムが $\operatorname{Pr} 55$ の NC 領域と結合して粒子内に取り込まれる (Step0). このとき tRNA などの様々な細胞由来の RNA も取り込ま れる ${ }^{13,14)}$. 粒子が放出されると PR が活性化され，まず p2-NC が切断される (Step1). この切断により NCを含む ポリ蛋白は $\mathrm{N}$ 末端の $\mathrm{MA}$ による膜内側のアンカーという 軛から逃れ，粒子内で自由に動けるようになってゲノム RNA との相互作用を強め二量体化を劇的に進行させる. しかし C末に $\mathrm{p} 1 / \mathrm{p} 6$ を融合させた状態の $\mathrm{NC}$ は十分に機能 を発揮できず，二量体化が未熟で緩いために見かけ上の分 子量が大きくなるなど，RNAがへテロな状態に陥る。ま
たこのとき, ウイルス粒子に取り込まれた細胞由来 RNA とゲノム RNA との非特異的結合が起きることでもへテロ な分子量の RNA が出現する可能性が考えられる。続いて p1-p6が切断されることで NC は身軽になり, ある程度機 能を発揮してゲノムの安定化／均一化に働くことで二量体 化が進行する (Step1.1). 次の MA-CA 切断ではRNAの 状態はさほど変わらないが, CA が自由になることでコア 形成のきっかけが出来, 粒子形態が変化する (Step2).さ らに NC-p1 が切断されることで NCは最終産物となり, 二量体化は完成し，粒子としての十分な感染能を獲得する (CA-p2)，しかし CAには p2 が融合したままであり，不 十分なコア形成が観察されるとの報告がある ${ }^{15)}$. 最終的 にすべてのサイトが切断されることで粒子形状, コア形成, ゲノム二量体化が完成したウイルス粒子となる。

粒子成熟はこうした様々なウイルス構成物の形態変化の みならずウイルスの感染能にも大きく影響しており， T 細 胞系への感染能解析からは, ウイルス RNAの成熟が逆転 写以外の感染過程にも重要な役割を担っている可能性が示 唆された，今後変異体の感染能のさらなる解析などを通じ てウイルス粒子成熟過程のより深い理解につなげていきたい. (図 $2 \sim 8$ は文献 12 より改変して引用)

\section{謝 辞}

本稿は大阪大学微生物病研究所の大石真久 ・櫻木小百合 博士並びに塩田達雄教授, 大阪医科大学の中野隆史 - 佐野 浩一先生ら共同研究者の方々のご協力の下行われた研究成 果を元に作成されました。ここにあらためて深謝いたします。 


\section{参考文献}

1) C. S. Adamson, K. Salzwedel and E. O. Freed. Virus maturation as a new HIV-1 therapeutic target. Expert Opin Ther Targets 13: 895-908, 2009.

2 ) A. H. Kaplan, M. Manchester and R. Swanstrom. The activity of the protease of human immunodeficiency virus type 1 is initiated at the membrane of infected cells before the release of viral proteins and is required for release to occur with maximum efficiency. J Virol 68: 6782-6, 1994.

3 ) A. G. Bukrinskaya. HIV-1 assembly and maturation. Arch Virol 149: 1067-82, 2004.

4) W. Fu and A. Rein. Maturation of dimeric viral RNA of Moloney murine leukemia virus. J Virol 67: 5443-9, 1993.

5 ) J. Kafaie, M. Dolatshahi, L. Ajamian, R. Song, A. J. Mouland, I. Rouiller and M. Laughrea. Role of capsid sequence and immature nucleocapsid proteins $\mathrm{p} 9$ and p15 in Human Immunodeficiency Virus type 1 genomic RNA dimerization. Virology 385: 233-44, 2009.

$6)$ M. Shehu-Xhilaga, H. G. Kraeusslich, S. Pettit, R. Swanstrom, J. Y. Lee, J. A. Marshall, S. M. Crowe and J. Mak. Proteolytic processing of the p2/nucleocapsid cleavage site is critical for human immunodeficiency virus type 1 RNA dimer maturation. J Virol 75: 915664, 2001.

7 ) S. C. Pettit, M. D. Moody, R. S. Wehbie, A. H. Kaplan, P. V. Nantermet, C. A. Klein and R. Swanstrom. The $\mathrm{p} 2$ domain of human immunodeficiency virus type $1 \mathrm{Gag}$ regulates sequential proteolytic processing and is required to produce fully infectious virions. J Virol 68: 8017-27, 1994.
8 ) J. Sakuragi, S. Sakuragi and T. Shioda. Minimal region sufficient for genome dimerization in the human immunodeficiency virus type 1 virion and its potential roles in the early stages of viral replication. J Virol 81: 7985-92, 2007.

9) D. Muriaux, H. De Rocquigny, B. P. Roques and J. Paoletti. NCp7 activates HIV-1Lai RNA dimerization by converting a transient loop- loop complex into a stable dimer. J Biol Chem 271: 33686-33692, 1996.

10) M. Cruceanu, M. A. Urbaneja, C. V. Hixson, D. G. Johnson, S. A. Datta, M. J. Fivash, A. G. Stephen, R. J. Fisher, R. J. Gorelick, J. R. Casas-Finet, A. Rein, I. Rouzina and M. C. Williams. Nucleic acid binding and chaperone properties of HIV-1 Gag and nucleocapsid proteins. Nucleic Acids Res 34: 593-605, 2006.

11) C. Aiken and S. Joyce. Immunology: TRIM5 does double duty. Nature 472: 305-306, 2011.

12) M. Ohishi, T. Nakano, S. Sakuragi, T. Shioda, K. Sano and J. I. Sakuragi. The relationship between HIV-1 genome RNA dimerization, virion maturation and infectivity. Nucleic Acids Res 39: 3404-3017, 2011.

13) D. Muriaux, J. Mirro, D. Harvin and A. Rein. RNA is a structural element in retrovirus particles. Proc Natl Acad Sci U S A 98: 5246-51, 2001.

14) S. J. Rulli, Jr., C. S. Hibbert, J. Mirro, T. Pederson, S. Biswal and A. Rein. Selective and Non-Selective Packaging of Cellular RNAs in Retrovirus Particles. J Virol 2007.

15) K. Wiegers, G. Rutter, H. Kottler, U. Tessmer, H. Hohenberg and H. G. Krausslich. Sequential steps in human immunodeficiency virus particle maturation revealed by alterations of individual Gag polyprotein cleavage sites. J Virol 72: 2846-54, 1998.

\title{
What's going on post-budding?
}

\section{Jun-ichi SAKURAGI, Ph.D.}

\author{
Dept. Viral Infections, RIMD, Osaka University
}

In general, the retrovirus particles become infectious on post-budding with cleavages of structural protein Gag by viral protease. Protease defective mutants bud particles normally, but the particles are non-infectious and called donuts-like particle because of their morphology. The viral genomes inside the donuts-like particles form very fragile dimer, which are far different from those in wild-type particles. The ordered particle maturation process is essential for infectivity of virus, but its mechanism largely remains unclear. We have constructed HIV-1 Gag cleavage site mutants to enable the steady state observation of virion maturation steps, and precisely study Gag processing, RNA dimerization, virion morphology and infectivity. As results, we found that these process progressed synchronously, but each transition point did not coincide completely. The mutual relationship between viral protein and RNA maturation is discussed for a further understanding of the retroviral life cycle. 